\title{
PROBLEMATIKA PEMBENTUKAN KARAKTER DI LEMBAGA PENDIDIKAN DAYAH
}

\author{
M. Arif Idris ${ }^{1}$, Suroto ${ }^{2}$ \\ ${ }^{1,2}$ Sekolah Tinggi Agama Islam Negeri Teungku Dirundeng Meulaboh \\ Email kontributor: suroto@staindirundeng.ac.id
}

\begin{abstract}
Abstrak
Dayah merupakan suatu lembaga pendidikan yang mengarah kepada proses pendidikan yang bersifat informal. Keberadaan Dayah di tengah-tengah kemajemukan masyarakat yang terdiri dari berbagai macam ras dan agama tentunya mempunyai problematika tersendiri dalam pembentukan karakter. Tujuan Penelitian ini untuk melihat bagaimana problematika pembentukan karakter di lembaga pendidikan dayah yang ada di Aceh. Jenis penelitian lapangan (field Research) dengan pendekatan penelitian dengan deskriptif kualitatif. Pengumpulan data melalui wawancara, studi dokumentasi dan observasi. Hasil dari penelitian menunjukkan bahwa problematika pendidikan dayah dalam pembentukan karakter santri di kabupaten Aceh Singkil, Kabupaten Simeuleu dan Kota Sabang ini berbeda-beda. Setidaknya ada tiga problematika yang dihadapi dayah dalam pembentukan karakter yaitu 1) Sains dan teknologi, 2) Dukungan orangtua, dan 3) Kesiapan lembaga Pendidikan dayah.
\end{abstract}

Kata kunci: Problematika, Karakter, Pendidikan

\begin{abstract}
Dayah is an educational institution that leads to an informal educational process. The existence of Dayah in the midst of a pluralistic society consisting of various races and religions certainly has its own problems in character building. The purpose of this study is to see how the problems of character building in dayah educational institutions in Aceh are. This type of field research (field research) with a qualitative descriptive research approach. Collecting data through interviews, study documentation and observation. The results of the study indicate that the problems of dayah education in shaping the character of students in Aceh Singkil, Simeuleu and Sabang districts are different. There are at least three problems faced by dayah in character building, namely 1) science and technology, 2) parental support, and 3) readiness of dayah educational institutions.
\end{abstract}

Keywords: Problematics, Character, Education 


\section{A. PENDAHULUAN}

Pendidikan merupakan hal yang sangat mendasar dalam kehidupan manusia untuk mengembangkan potensi diri dalam berbagai aspek. Pendidikan merupakan usaha sadar dan terencana untuk mewujudkan suasana belajar dan proses pembelajaran agar peserta didik secara aktif mengembangkan potensi dirinya untuk memiliki kekuatan spiritual, keagamaan, pengendalian diri, kepribadian, kecerdasan, akhlak mulia, serta keterampilan yang diperlukan dirinya, masyarakat, bangsa dan negara.

Indonesia dikenal sebagai masyarakat yang berjiwa relegius, tentunya tidak mengherankan apabila Indonesia memiliki banyak warisan budaya keagamaan yang sejak dahulu hingga sekarang masih terjaga dan terpelihara. Salah satu warisan lembaga pendidikan tradisional keagamaan masyarakat Indonesia yang dominan atau mayoritasnya berpenduduk muslim, ialah pondok pesantren atau dayah. Lembaga pendidikan dayah ini telah muncul pada abad ke 9 atau ke 10 dan merupakan lembaga tertua yang monumental sebagai lembaga warisan tradisi keagamaan umat Islam di masa itu hingga saat ini. Sehingga tidaklah mengherankan apabila pondok pesantren menjadi sebuah lembaga yang benar-benar telah mengakar dan dikenal dengan masyarakat Islam di Indonesia.

Di Indonesia, Dayah digunakan sebagai salah satu saluran proses Islamisasi di Indonesia. Uka Tjandrasasnita mengatakan bahwa sebelum abad ke-13 merupakan tahap islamisasi. Abad ini juga disebut sebagai masa pertumbuhan berbagai kerajaan yang bercorak Islam yang pertama di Indonesia (Mahalli, 2018). Aceh merupakan suatu daerah yang merupakan salah satu provinsi di Indonesia dulunya terkenal di seluruh dunia, sebagai wilayah pernah berkembang kerajaan Islam yang puncak kejayaannya pada masa pemerintahan Sultan Iskandar Muda (1607-1637) memiliki kekhususan dibidang agama, karena itulah Aceh disebut dengan "Daerah Istimewa Aceh". Kekhususan ini sekarang telah menunjukkan identitas yang lebih khusus dalam bidang dayah (Mahalli, 2018).

Dayah merupakan lembaga pendidikan tertua di Aceh. Eksistensinya telah membawa kontribusi yang sangat positif terhadap pencerdasan masyarakat Aceh, terutama dalam konteks internalisasi nilai-nilai ajaran Islam dan juga telah memainkan peran sebagai fungsi kontrol sosial masyarakat Aceh (Mashuri, 2013). Dayah Merupakan suatu lembaga pendidikan yang mengarah kepada proses pendidikan yang bersifat informal. Sistem pendidikan didayah berbeda dengan system pendidikan yang diterapkan pada sekolah umum lainnya. Artinya dayah lebih menekankan pendidikanya terhadap ilmu-ilmu Islam. Ada sebagian dayah hanya menerapkan Pendidikan Islam yang hanya memepelajari ilmu-ilmu Keislaman, misalnya: Fikih, Akidah, syariat dan lain-lain. Tanpa mempelajari ilmu-ilmu yang telah ditetapkan kurikulumnya oleh dinas-dinas terkait sesuai dengan standar kurikulum nasional.

Dayah ini dinamakan dengan dayah tradisional atau biasa disebut dengan dayah salafi. Dayah salafi ini tetap mempertahankan elemen-elemen tradisionalnya, yaitu pondok, mesjid, tengku, kyai, santri dan kitab-kitab klasik. Namun, ada juga dayah yang menerapkan sistem pendidikan yang mengadopsi dua sistem pendidikan sekaligus, yakni sistem pendidikan nilai-nilai ilmu keislaman dengan pendidikan yang menggunakan system kurikulum standard nasional, dayah ini dinamakan dengan dayah modern. Zamaksyari (1984) mengatakan sebagaimana yang dikutip Sri Suyanta bahwa unsur penting dari Dayah adalah pimpinan (teungku, Kyai), orang yang belajar (siemedagang, santri), asrama pondok sebagai tempat tinggal, mesjid dan pengkajian kitab kuning. 
Disisi lain, tanpa bisa dipungkiri bahwa pendidikan karakter menjadi kebutuhan mendasar bagi masyarakat. Karakter merupakan aspek penting dari kualitas SDM karena kualitas karakter bangsa menentukan kemajuan suatu bangsa. Karakter yang berkualitas perlu dibentuk dan dibina sejak usia dini. Usia dini merupakan masa kritis bagi pembentukan karakter seseorang. Menurut Freud kegagalan penanaman kepribadian yang baik di usia dini ini akan membentuk pribadi yang bermasalah di masa dewasanya kelak. Kesuksesan orang tua membimbing anaknya dalam mengatasi konflik kepribadian di usia dini sangat menentukan kesuksesan anak dalam kehidupan sosial di masa dewasanya kelak (Masnur, 2011).

Secara etimologis, kata karakter (Inggris: character) berasal dari Bahasa Yunani (Greek), yaitu charassein yang berarti "to engrave". Kata "to engrave" bisa diterjemahkan mengukir, melukis, atau menggoreskan (Ryan, K., \& Bohlin, 1999). Dalam istilah bahasa Arab, karakter memiliki kemiripan makna dengan ahlak yaitu tabiat atau kebiasaan melakukan hal yang baik. AlGhazali menggambarkan bahwa akhlak adalah tingkah laku yang berasal dari hati yang baik. Oleh karena itu pendidikan karakter adalah usaha aktif untuk membentuk kebiasaan baik (habit), sehingga sifat anak sudah terukir sejak kecil (Megawangi, 2004).

Karakter terdiri dari tiga bagian yang saling terkait yaitu pengetahuan tentang moral (moral knowing), perasaan (moral feeling), dan perilaku bermoral (moral behavior) (Lickona, 2009). Karakter yang baik terdiri dari mengetahui kebaikan (knowing the good), mencintai atau menginginkan kebaikan (loving atau desiring the good), dan melakukan kebaikan (acting the good). Oleh karena itu, cara membentuk karakter yang efektif adalah dengan melibatkan ketiga aspek tersebut.

Pendidikan karakter merupakan proses menanamkan nilai-nilai kehidupan untuk dikembangkan dalam kepribadian seseorang, sehingga menjadi satu dalam perilaku kehidupan individu tersebut. Untuk itu, proses penanaman nilai-nilai positif kepada peserta didik harus dilakukan agar mereka memiliki karakter yang baik sesuai dengan nilai-nilai yang dirujuk baik dari agama, budaya, maupun falsafah bangsa.

Mengulas tentang permasalahan pendidikan khususnya dalam mempersiapkan karakter masyarakat dan bangsa menjadi penting mengingat pendidikan karakter telah banyak dibahas dan dikaji secara terus menerus. Dalam hal ini Permasalahan pendidikan karakter harus dilihat secara lebih luas mengingat pendidikan karakter ini sangat tekait dengan berbagai elemen yang saling mendukung sebagai sebuah sistem utuh. Atas dasar itulah, perlu adanya konsep pendidikan dengan tujuan mewujudkan dan mengantarkan anak didik agar mempunyai keluasan pengetahuan dengan dilandasi nilai-nilai akhlak yang mulia, sehingga kedalaman ilmu pengetahuan yang diperoleh nantinya dapat dimain-perankan dengan benar. Sebab kedalaman ilmu yang dimiliki seseorang tanpa dilandasi nilai- nilai akhlak mulia, juga akan dapat menimbulkan kerugian pada dirinya sendiri dan orang lain (Fuad, 2012).

Rapuhnya karakter dan budaya dalam kehidupan berbangsa bisa membawa mundurnya peradaban bangsa. Masyarakat yang memiliki karakter dan budaya yang kuat akan semakin memperkuat eksistensi suatu bangsa. Saat ini pendidikan formal di sekolah saja tidak cukup, pengaruh lingkungan dan kehidupan modern yang berkembang membuat orangtua dan guru harus lebih waspada terhadap hal-hal negatif yang bisa merasuki pikiran anak. Agar anak-anak penerus generasi menjadi anak yang baik, sholeh dan berhasil dalam kehidupan masyarakat bukan hanya 
dibutuhkan kepandaian dan ilmu yang tinggi, tetapi juga harus diimbangi dengan pembentukan karakter.

Degradasi moral ini disepakati oleh para ahli pendidikan Islam, meskipun mereka berbeda pendapat tentang bentuk dan sebab terjadinya. Ada yang mengganggap kemerosotan ini terjadi karena ketidak lengkapan aspek materinya, ada yang menganggap karena terjadinya krisis sosial masyarakat akibat masyarakat meninggalkan budayanya, ada pula yang menganggap karena kurangnya teladan dari orang yang lebih tua dan penanaman akidah yang benar (Fitri, 2018).

Degradasi moral yang menjadi problematika saat ini, perlu dicarikan solusinya melalui pendidikan, sebab pendidikan merupakan kebutuhan bagi ummat manusia, hingga kini masih dipercaya sebagai media yang sangat ampuh dalam membangun kecerdasan, sekaligus kepribadian anak menjadi lebih baik untuk membentuk aspek-aspek dalam diri manusia (Bahrudin \& Rifa'i, 2021)

Menyiapkan pribadi yang berkarakter, dapat dilakukan oleh semua institusi pendidikan mulai dari pesantren, sekolah, masyarakat, dan keluarga. Ketika banyak orang yang mengkaji dan mendiskusikan tentang konsep itu, pesantren telah menerapkannya jauh sebelum itu. Pesantren menjadi tempat yang tepat dalam mengimplementasikan pendidikan karakter, terlebih pada pesantren tasawuf (Fuad, 2012).

Pesantren salafiah atau dayah adalah lembaga pendidikan yang sudah tersebar ke seluruh pelosok negeri. Kesederhanaan, kearifan lokal, falsafah dan pola pendidikannya sudah mengakar pada sebagian besar masyarakat, khususnya dalam pendidikan berbasis agama Islam. Secara tidak langsung dan tidak formal pendidikan karakter telah ditanamkan secara kuat dengan pola dan teknik yang khas pesantren salafiah. Pendidikan karakter sesungguhnya tidak harus menggunakan kurikulum yang formal, cukup dengan hidden curriculum. Pendidikan karakter tidak selalu diajarkan dalam kelas, namun dilakukan secara simultan dan berkelanjutan di dalam dan di luar kelas (Sumardi, 2012).

Sekarang Dayah telah terdapat di seluruh Aceh dengan tipe dan jenis-jenisnya. Terlepas dari pengaruh besarnya terhadap orang Aceh. Tentunya perkembangannya bukan tanpa persoalan, persoalan tersebut dapat muncul dari berbagai situasi dan kondisi dimana dayah tersebut berada. Keberadaan dayah yang terdapat di wilayah-wilayah atau kabupaten-kabupaten terjauh dengan pusat ibukota provinsi pastinya terdapat kesenjangan, misalnya dari sarana dan prasarana, dan tenaga pengajar, benturan budaya, faktor keberagaman agama. Bisa dikatakan problem-problem tersebut sangat berpengaruh terhadap perkembangan dayah tersebut yang berujung kepada pembentukan karakter dan inovasi para santrinya. Aceh Singkil misalnya daerah yang langsung berbatasan dengan Sumatera Utara yang sebagian pendudukya beragama non muslim dimana budaya dan adat istiadatnya berbeda membaur tanpa batasan. Gesekan Budaya dan agama merupakan suatu persoalan sendiri di Kabupaten ini, sehingga dayah berperan penting dalam membentengi hal tersebut sehingga berdampak kepada proses pendidikan karakter santri. Simeulue sebagai sebuah kabupaten kepulauan yang jauh dari Ibu Kota provinsi ini memiliki masalah tersendiri di antaranya persoalan yang sering diangkat yakni sarana prasarana, serta sumber daya manusia di antaranya tenaga pendidikan, serta perbedaan budaya. Permasalahan ini sangat berpengaruh bagi Dayah dalam pembentukan karakter santri.

Terakhir Kota sabang, kota yang menjadi destinasi wisata ini, benturan kebudayaan dengan wisatawan asing, baik wisatawan manca negara dan domestik yang berdatangan di kota ini menjadi 
persoalan tersendiri. Dari ketiga permasalahan di atas setidaknya dapat mempengaruhi karakter santri. Di sisi lain Manhaj dan inovasi pesantren pun berperan penting dalam pembentukan karakter santri. Tentunya berbagai persoalan tersebut secara tidak langsung akan berdampak pada karakter santri santri itu sendiri. Karenanya dalam penelitian ini penulis mengangkat permasalahan yang dimunculkan dalam sebuah judul Problematika Pembentukan Karakter di Lembaga Pendidikan Dayah (Studi Pada Kabupaten Aceh Singkil, Kabupaten Simeulue dan Kota Sabang).

Adapun yang menjadi rumusan masalah disini adalah bagaimana problematika pendidikan Dayah dalam pembentukan karakter santri diwilayah Aceh Singkil, Simeulue, dan Sabang, dan yang menjadi tujuan penelitian adalah untuk mengetahui problematika pendidikan Dayah dalam pembentukan karakter santri diwilayah Aceh Singkil, Simeulue, dan Sabang. Kajian terdahulu terdapat pada artikel yang ditulis oleh Mashuri (2013) dengan judul "Dinamika Sistem Pendidikan Islam di Dayah”. Tulisan ini dimuat dalam jurnal Ilmiah DIDAKTIKA VOL.XIII, NO.2, 259-270. Tahun 2013. Artikel ini menerangkan: Lembaga pendidikan Islam di Dayah dewasa ini telah mengalami dinamika perubahan yang sangat signifikan, dengan mengambil bentuk kekinian disamping mempertahankan sistem lama yang masih relevan, terutama dalam konteks perubahan bentuk fisik, di antaranya bentuk bangunan Dayah yang sudah modern, terdapatnya gedunggedung perkantoran dan juga tersedianya fasilitas-fasilitas umum lainnya. Adapun perubahan dalam non-fisik, seperti telah digunakannya kurikulum baru yang selama ini tidak pernah digunakan. Adapun faktor-faktor perubahan Dayah dewasa ini, yaitu: 1. Tuntutan masyarakat atau dunia kerja yang semakin hari semakin meningkat, 2. Faktor arus moderenisasi dan globalisasi yang begitu dahsyat

\section{B. METODE PENELITIAN}

Penelitian ini menggunakan pendekatan penelitian kualitatif dimana penelitian kualitatif sebagai metode ilmiah yang sering digunakan dan dilaksanakan oleh sekelompok peneliti dalam bidang ilmu sosial, termasuk juga ilmu pendidikan. Pendekatan penelitian kualitatif adalah suatu proses penelitian dan pemahaman yang berdasarkan pada metode yang menyelidiki suatu fenomena sosial dan masalah manusia. Pada penelitian ini peneliti membuat suatu gambaran kompleks meneliti kata-kata laporan terinci dari pandangan responden dan melakukan studi pada situasi yang alami.

Alat pengumpulan data menggunakan pengamatan langsung, wawancara, studi dokumen. Penelitian tentang problematika pembentukan karakter di lembaga pendidikan dayah relevan dengan menggunakan penelitian kualitatif karena memenuhi karakteristik penelitian kualitatif, terutama dalam hal pengungkapan data secara mendalam melalui wawancara, observasi dan kajian dokumen terhadap apa yang dilakukan para informan, sebagaimana mereka melakukan kegiatan, untuk apa kegiatan dilakukan dan mengapa mereka melakukan kegiatan dalam realitas yang sesungguhnya.

Penelitian ini berpusat di tiga wilayah, wilayah tersebut yakni Kabupaten Aceh Singkil, Kabupaten Simeulue dan Kota Sabang. Adapun yang menjadi objek penelitian adalah DayahDayah yang ada di wilayah Kabupaten Aceh Singkil, Kabupaten Simeulue dan Kota Sabang. Dayah yang dipilih adalah Dayah yang sudah terkenal dan memiliki peran yang sangat central di daerah tersebut. Penyajian data dilakukan untuk memahami apa yang terjadi selama penelitian berlangsung. Selanjutnya, Verifikasi data dilakukan apabila kesimpulan awal yang dikemukakan 
masih bersifat sementara, dan akan ada perubahan-perubahan bila tidak diikuti bukti-bukti pendukung yang kuat untuk mendukung pada tahap pengumpulan data berikutnya.

\section{HASIL DAN PEMBAHASAN}

\section{Pembentukan Karakter di Lembaga Pendidikan Dayah di Aceh}

Pondok pesantren atau dayah merupakan suatu lembaga pendidikan agama Islam yang tumbuh serta diakui masyarakat sekitar dengan sistem asrama (komplek), dimana santri menerima pendidikan agama melalui sistem pengajian atau madrasah yang sepenuhnya berada dibawah kedaulatan dari leadership seorang atau beberapa orang kiai dengan ciri-ciri khas yang bersifat kharismatik serta independen dalam segala hal (H. M. Arifin, 1996). Pesantren pada mulanya didirikan sebagai lembaga dakwah namun pada tahap selanjutnya menjadi lembaga pendidikan karena berdakwah melalui pendidikan dirasa cukup efisien dalam pesantren ada lima unsur yang tidak bisa dipisahkan dengan pesantren yaitu: adanya Kiai, ada pondok, ada masjid, ada santri dan ada pengajaran kitab kuning. Lima elemen ini adalah elemen-elemen yang tidak bisa dipisahkan dari pesantren dan ini menjadi ciri khas pendidikan pesantren (Ubaidillah, 2016). Adapun peran pesantren yakni:

a. Sebagai pusat berlangsungnya transmisi ilmu-ilmu Islam tradisional,

b. Sebagai penjaga dan pemelihara keberlangsungan Islam tradisional, dan

c. Sebagai pusat reproduksi ulama.

Kehadiran pesantren tidak bisa lepas dari peran masyarakat sekitarnya yang merupakan ruang lingkup dan salah satu objek penentu dalam keberlangsungan pesantren. Oleh karena itu, pesantren akan berhadapan dengan gejala sosial yang sarat adanya perubahan. Perubahan sosial tentunya berdampak terhadap formulasi pesantren, karena pesantren juga merupakan lembaga sosial. Oleh karenanya, pesantren mau tidak mau harus berpartisipasi dalam mengatasi problem empiris masyarakat seperti kemiskinan, kebodohan, kerusakan lingkungan, keterbatasan sumber daya alam, degradasi moral, dan lainnya. Partisipasi ini perlu dilakukan agar kehadiran pesantren tetap relevan dengan perkembangan dan tuntuan masyarakat dan tidak mengalami disintegrasi dengan dinamika kehidupan sosial.

Pesantren sebagai pusat pengembangan keagamaan harus mampu membekali santrinya dengan kemampuan religiusnya melalui penanaman nilai-nilai agama sebagaimana yang tertuang dalam kajian-kajian yang bersumber dari al-Qur'an dan Hadis. Penanaman nilai-nilai agama itu mesti ditanamkan sekokoh mungkin agar menjadi benteng yang kuat sehingga siap berkompetisi dalam dialektika kehidupan yang sarat adanya perubahan.

Di dunia pesantren pendidikan karakter bukanlah hal yang baru, sebab sejak dini meanstream (pengarusutamaan) karakter santri sudah dikedepankan melalui pendidikan akhlak. Di pesantren persoalan akhlak menjadi persoalan yang sangat urgen, sebenarnya pesantren telah lama mendidik santrinya agar memiliki karakter yang dapat diandalkan, seperti karakter bidang keilmuan, karakter bidang akhlak dan karakter bidang social (Z. Arifin, 2014).

Transformasi nilai-nilai pendidikan pesantren yang berlangsung sepanjang tahun, melalui berbagai sarana (lisan, tulisan perbuatan dan kenyataan), telah mampu memadukan seluruh komponen pesantren dalam satu barisan. Sehingga tidak terjadi tarik-menarik kepentingan dan orientasi antara satu pihak dengan lainnya. Semuanya melandasi gerak langkahnya dengan bahasa 
keikhlasan, kesederhanaan, kesungguhan, perjuangan dan pengorbanan untuk menggapai ridha Allah. Semua mempunyai pengertian dan keterpanggilan akan tanggungjawab untuk merealisasikan visi dan misi pendidikan pesantrennya. Semua mempunyai keterikatan pada sistem hingga kultur yang sudah terbentuk di pesantren. Karena mereka semua mempunyai kesadaran, keterpanggilan dan loyalitas baik kepada nilai, sistem maupun pemimpin. Soliditas ini menumbuhkan kekuatan yang dahsyat dalam proses pendidikan karakter di pesantren (Triyono, 2017).

Mengenai proses pembentukan karakter di Dayah yang ada di Aceh khususnya di kawasan Aceh singkil, Pimpinan pondok pesantren Darul hasanah Aceh Singkil menyebutkan bahwa:

Salah satu upaya yang dilakukan adalah dengan mengadakan tawajuh. Melalui kegiatan tawajuh sisi spiritual santri akan dibina lagi. Dan itu memberikan dampak yang positif, ada yang belum masuk tarikat dan setelah masuk tarikat dia ada perubahan, adab semakin kuat semakin tinggi kepatuhan dan kerajinan meningkat. Dilarang menggunakan HP, radio dan alat elektronik lain sejenisnya. Untuk mengatasi kejenuhan dan membuka wawasan santri juga diadakan nonton bareng film -film sejarah dan perkembangan pesantren yang ada di Indonesia (Hasil Wawancara).

Berdasarkan hasil penelitian di atas diketahui bahwa salah satu upaya yang dilakukan dipondok pesantren Darul Hasanah Aceh Singkil dalam menguatkan karakter keislaman dan tasawuf adalah dengan melaksanakan tawajuh. Tawajuh merupakan ritual yang sering dilaksanakan di Dayah-dayah di Aceh. Menurut Maruf (2018), nilai-nilai edukatif dalam tasawuf yang diterapkan melalui tawajuhan ada tiga hal yaitu kedamain dan ketenangan hati, tawadhu' (rendah diri atau rendah hati), dan kebahagiaan lahir dan batin. Adapun manfaat dari nilai-nilai edukatif dalam tasawuf yang diterapkan meliputi tazkiyatun nafs (penyucian jiwa) dan peningkatan ibadah dan ketakwaan kepada Allah SWT.

Selanjutnya dukungan dari orangtua juga sangat dibutuhkan guna menunjang proses pembentukan karakter santri. Orangtua harus terus membimbing dan mendampingi anak dalam melaksanakan pendidikannya. Sebagaimana diketahui bahwa orangtua merupakan peletak dasar nilai-nilai akhlak pada anak. Orangtua dalam hal ini keluarga merupakan lembaga pendidikan pertama bagi setiap individu.

Selanjutnya di Dayah di Dayah Darul Aitami Kabupaten Simeuleu, proses pembentukan karakter yang dilakukan dengan beberapa tahapan, yakni 1) dengan tahapan pengenalan. Ustadz memperkenalkan berbagai karakter dilingkungan dan keluarga. 2) dengan pemahaman, ustadz memberikan pemahaman tentang karakter. 3) pengulangan atau pembiasaan, tahap ini dibutuhkan kesadaran dari dalam diri sendiri. 4) tahap pembudayaan, karakter perlu dibudayakan dalam kehidupan masyarakat dan keluarga. Pimpinan dayah tersebut mengutarakan bahwa "empat tahapan dalam pembentukan karakter, pertama pengenalan, kedua pemahaman, ketiga pengulangan atau pembiasaan.

Data di atas memberikan pemahaman bahwa aktivitas di dayah yang berkesinambungan secara tidak langsung memberikan pengaruh yang besar dalam membentuk karakter santri. Hampir di semua Dayah/pondok pesantren, rentetan aktifitas santri terintegrasi ke dalam pendidikan yang menghendaki kekokohan jiwa dan hal ini nantinya akan menjadi benteng kekuatan dan bekal mereka ketika kembali ke lingkungannya masing-masing. Realitas aktifitas di pesantren yang terjadi secara berkesinambungan telah menanamkan karakter-karakter yang menjadi identitas 
santri. Inilah sisi keberhasilan pesantren dalam penanaman pendidikan karakter, karena pada prinsipnya penanaman karakter akan lebih efektif melaui pembiasaan dan teladan yang diawasi langsung oleh gurunya (Fauzan, 2015).

Selanjutnya, Zarkasyi (2005) menyatakan bahwa pesantren mempunyai keunggulan dan karasteristik khusus dalam mengaplikasikan pendidikan bagi anak didiknya (santri). Hal itu dikarenakan:

a. Adanya jiwa dan falsafah Jiwa dan falsafah yang ditanamkan kepada santri akan menjamin kelangsungan lembaga pendidikan bahkan menjadi motor penggerak bagi seluruh penghuni pesantren. Diantara falsafah itu yaitu Panca Jiwa yang terdiri dari; (a) keihklasan, (b) kesederhanaan, (c) kemandirian, (d) ukhuwah Islamiyah, dan (e) kebersamaan dalam menentukan lapangan perjuangan dan kehidupan.

b. Terwujudnya integralitas dalam jiwa, nilai, sistem dan standar operasional pelaksanaan Terciptanya integralitas yang solid pada jajaran para pendidik hingga anak didik, terhadap pemahaman jiwa, nilai, visi, misi dan orientasi, sistem hingga standar operasional pelaksanaan yang sama, sehingga mampu memadukukan seluruh komponen pesantren dalam satu barisan.

c. Terciptanya tri pusat pendidikan yang terpadu Tri pusat pendidikan terpadu merupakan tiga faktor yang menopang dan mendukung keberhasilan pendidikan yang terdiri dari pendidikan sekolah, pendidikan keluarga, dan pendidikan masyarakat.

d. Totalitas pendidikan. Pesantren menerapkan totalitas pendidikan dengan mengandalkan keteladanan, penciptaan lingkungan dan pembiasaan melalui berbagai tugas dan kegiatan.

Berbeda halnya dengan apa yang dilakukan oleh dayah di daerah Aceh lainnya, daerah Sabang memiliki keunikan tersendiri. Berdasarkan karakter daerahnya sebagai wilayah wisata, Sabang merupakan destinasi wisata yang pastinya akan dimasuki oleh ragam etnis, ragam bangsa dan negara yang membawa macam-macam paham, budaya dan itu menjadi potensi bersentuhannya ragam budaya di kalangan masyarakatnya. Dalam situasi yang multikultural ini, merubah karakter merupakan tantangan, tantangannya lumayan besar.

Salah satu pendekatan yang dilakukan dalam pembentukan karakter remaja di Sabang adalah Pendekatan kemasyarakatan. Hal ini sebagaimana yang dijelaskan oleh salah seorang tokoh agama di Sabang bahwa:

Salah satu pendekatan pembentukan karakter yang dilakukan di kota Sabang adalah pendekatan kemasyarakatan. Pendekatan yang dimaksud adalah ustadz-ustadz mengisi pengajian di masjid, menjadi khatib, menjadi narasumber, ini cara-cara pendekatan kepada masyarakat karena masyarakat masih kental kedaerahannya. Selanjutnya, di lingkungan pesantren, pihak dayah melakukan kerjasama dengan wali santri, dengan komite sekolah untuk sama-sama melaksanakan pendidikan karakter di lingkungan keluarga, sekolah/dayah, maupun lingkungan masyarakat. Pihak Dinas syariat islam kota juga turut andil dalam melakukan publikasi nilai-nilai islam dan akhlakul karimah melalui website, facebook dan lain sebagainya dengan harapan informasi tersebut bisa menambah wawasan dan pemahaman masyarakat tentang pentingnya membangun karakter remaja (hasil Wawancara). 
Menurut analisa penulis, pendekatan kemasyarakatan menjadi salah satu alternatif pendekatan yang patut dicoba. Sebagaimana yang diketahui bahwa masyarakat merupakan lembaga pendidikan terluas dan tidak berbatas. Dalam masyarakat, belajar dapat dilakukan dalam banyak hal, baik itu melalui pengalaman, petuah-petuah tokoh maupun cerita-cerita rakyat yang sarat nilai-nilai akhlakul karimah.

\section{Problematika yang dihadapi Dayah dalam Pembentukan Karakter Santri}

Mengenai problematika yang dihadapi oleh Dayah di Aceh dalam membentuk karakter santri akan penulis uraikan ke dalam beberapa poin berikut:

\section{a. Budaya, Sains dan teknologi Informasi}

Mengenai merosotnya karakter santri selama ini khususnya di daerah Singkil, Pimpinan pondok pesantren Darul hasanah Aceh Singkil menyebutkan bahwa "hadirnya lembaga umum dan kurangnya dukungan orang tua menjadi salah satu faktor pemicunya". Pergeseran nilai terjadi selama hadirnya sekolah umum. Sejak 2006 disingkil sudah ada lembaga umumnya, jadi dengan adanya lembaga umum ini ada dampak pergeseran nilai, karena sudah dibebani dengan pelajaran pelajaran umum. Di pelajaran umum ada waktu untuk keluar dari pondok pesantren dan bergaul dengan orang-orang diluar memberi dampak juga.

Tidak jauh berbeda dengan problematikan yang di alami oleh Darul hasanah, dayah Babussalam dalam upaya pembentukan karakter di Singkil juga memiliki beberapa problematika antara lain adalah sains teknologi dan budaya non muslim. Hal ini sebagaimana yang disampaikan pimpinan dayah bahwa:

Hadirnya sains dan Teknologi itu ada dampaknya. Beliau mengumpamakan dampaknya sebagaimana dampak bagusnya jalan terhadap tingginya angka kecelakaan. Kenapa kecelakaan dijalan raya? Ya karena jalannya aspal coba jalannya jalan setapak. Teknologi seperti Gawai memang banyak memberikan kemudahan, tapi dampak negatifnya juga besar. Wilayah singkil yang multikultural dan multi agama juga memberikan dampak besar terhadap pembentukan karakter remaja di kota Singkil (hasil wawancara).

Gawai telah banyak memberikan dampak terhadap dunia pendidikan, dimana arus komunikasi dan informasi mengalir dengan begitu cepat sehingga dapat diakses dengan mudah oleh semua orang tanpa mengetahui dari mana asal mula informasi tersebut. Oleh karenanya, dampak adanya gawai ada yang sifatnya positif maupun negatif. Dampak positifnya yakni dapat digunakan sebagai media pembelajaran dalam proses belajar peserta didik sehingga dapat menambah pengetahuan, menambah teman, mempermudah komunikasi, dan munculnya metode pembelajaran yang baru. Sedangkan dampak negatifnya, yakni gawai disalahgunakan oleh anak untuk bermain game secara terus menerus sehingga membuat mereka kecanduan, gawai digunakan untuk menonton video-video porno.

Penggunaan gawai yang terus menerus dapat merusak fisik anak, diantaranya merusak mata, mengubah postur tubuh, kulit wajah menjadi kendur, mengganggu pendengaran, dan mengganggu saat anak istirahat. Namun dampak yang paling terasa yakni perkembangan karakter anak menjadi kurang baik. Pertama, anak yang kecanduan gawai akan sulit untuk berinteraksi dan bersosialisasi dengan orang-orang yang ada di sekitarnya karena mereka lebih fokus terhadap gawai yang ada di genggamannya. Kedua, anak yang kecanduan gawai akan cenderung memiliki 
sikap membela diri, berontak, dan emosional pada saat ada upaya dari seseorang untuk menghentikan penggunaan gawai tersebut. Ketiga, anak akan berani untuk bersikap bohong atau mencuri waktu untuk sekadar bermain gawai. Keempat, banyak fitur atau aplikasi dalam gawai yang tidak sesuai dengan karakter usia anak, miskin akan nilai norma-norma terutama norma agama (Hendayani, 2019).

Pesantren sebagai salah satu lembaga yang memegang peranan penting dalam mentransfer konsepsi agama Islam, sudah seharusnya memiliki peran yang kuat dalam mengawal adanya perubahan sosial. Terlebih lagi kehadiran pesantren menjadi salah satu lembaga yang sangat diharapkan masyarakat dalam mewarnai corak perubahan sosial terutama dalam pembentukan karakter masyarakat. Oleh karenanya, pesantren mau tidak mau harus berani tampil menjadi lembaga sebagai agen of change (agen perubahan) yang mampu mewarnai eskalasi arus masyarakat yang sudah mulai tergerus oleh kekuatan Barat. Sementara kekuatan Barat memiliki kekuatan luar biasa yang mana dampaknya dapat mencerabut tatanan kehidupan sosial.

Penanaman konsep pendidikan karakter di pesantren secara konsisten dirasa mampu memgbendung laju budaya Barat. Karena pesantren memiliki pola pendidikan yang berbeda dengan pola pendidikan pada umumnya. Di pesantren terdapat pengawasan yang ketat menyangkut tata norma terutama tentang peribadatan khusus dan norma-norma muamalah tertentu (Fauzan, 2015).

\section{b. Dukungan Orangtua}

Pembentukan dan pengembangan karakter diawali dari lingkungan keluarga sebagai model utama atau teladan pengembangan karakter anak untuk mewujudkan manusia sebagai makhluk individu, sosial, berakal dan religius (Alwi, 2014). Orang tua atau orang dewasa sekitarnya hendaknya memberikan contoh yang baik pada berbagai aspek perkembangan anak.

Pimpinan pondok pesantren Darul hasanah Aceh Singkil juga menyebutkan bahwa dukungan orangtua juga menjadi salah satu problematika yang dihadapi oleh dayah dalam membentuk karakter santri. Hal ini sebagai hasil wawancara penulis dengan beliau yang menyebutkan bahwa:

Selanjutnya dukungan dari orang tua hanya bersifat materi bukan bersifat dukungan moral juga menjadi penyebab terjadinya pergeseran nilai karakter. Hanya memberikan materi, tapi ketika pulang tidak pernah ditanyakan bagaimana perkembangan, tidak pernah dikontrol, hal ini menyebabkan pergeseran nilai tersebut. Dapat dibandingkan bahwa kalau dulu dari jauh saja guru berdiri sudah ada rasa segan, rasa takut, tapi kalau sekarang tidak bahkan kalau kita panggil beberapa kali pun tidak nyahut. Ketika libur tidak ada kerjasama orang tua untuk mengontrol, hanya bersifat materi saja, biaya saja, pendidikan tidak pernah diperhatikan, hanya beberapa orang saja yang diperhatikan. Tapi umumnya hampir delapan puluh persen pergeseran nilai itu sangat terlihat. Orangtua sudah tidak lagi menjadi teladan bagi anak di rumah (hasil wawancara).

Hal di atas memberikan gambaran bahwa persoalan pembentukan karakter menjadi lebih rumit ketika orangtua selaku guru utama anak tidak mampu memerankan fungsinya secara baik dan tepat. Para orangtua lebih mengutamakan pekerjaan dan karir dan meninggalkan tanggungjawab utama mereka untuk mendidik dan membimbing anak menjadi pribadi yang baik dan berakhlak mulia. 
Pendidikan karakter berisi tiga tahapan kegiatan, yaitu menanamkan pengetahuan tentang karakter, perasaan tentang karakter, dan tindakan yang mencerminkan karakter (Novita et al., 2015). Menilik tiga tahapan kegiatan tersebut, dapat diketahui bahwa sebetulnya pendidikan karakter sama dengan pendidikan jenis lainnya, yakni harus menyentuh tiga ranah kejiwaan manusia, yakni ranah kognitif, afektif, dan psikomotorik (Park \& Peterson, 2006).

Sebagaimana yang diketahui bahwa dalam pendidikan karakter, keteladanan diperlukan dalam setiap lingkungan pendidikan, yakni lingkungan keluarga, sekolah, dan masyarakat. Di lingkungan keluarga, keteladanan orang tua sangat diperlukan dalam pendidikan karakter. Keteladanan orang tua menentukan keberhasilan peserta didik dalam proses kepemilikan pengetahuan tentang karakter, perasaan tentang karakter, dan tindakan yang mencerminkan karakter (Munawwaroh, 2019). Orang tua yang tidak mengetahui sopan santun akan menularkan ketidaktahuannya itu kepada anaknya, sehingga akan menciptakan anak yang tidak mengetahui sopan santun pula. Orang tua yang tidak mempunyai perasaan akan pentingnya sopan santun cenderung akan bersikap acuh terhadap anaknya sehingga membiarkan anaknya melakukan perilaku tidak sopan, sehingga anaknya pun tidak memiliki perasaan akan pentingnya sopan santun. Orang tua yang tidak memiliki perilaku tidak sopan akan menampakkan ketidaksopanannya di hadapan anak, sehingga anak setiap saat melihat perilaku tidak sopan kedua orang tuanya, dan akhirnya anak akan meniru perilaku tidak sopan yang senantiasa dilakukan oleh kedua orang tuanya. Hal ini sejalan dengan pendapat yang mengatakan bahwa anak yang memiliki pengetahuan karakter, perasaan karakter, dan tindakan karakter yang rendah disebabkan oleh keteladanan orang tua yang rendah dalam ketiga aspek tersebut (Novita et al., 2015).

\section{c. Kesiapan Lembaga Pendidikan Dayah}

Di sisi lain, hasil penelitian yang penulis lakukan khususnya di wilayah Aceh Singkil juga menunjukkan bahwa setidaknya ada dua problematika lain yang dihadapi dayah di singkil khususnya Dayah Darul Hasanah dalam upaya pembentukan karakter, yakni 1) terkait kesiapan lembaga dan 2) bangunan fisik. Dari segi kesiapan lembaga, problematika utama yang dihadapi adalah kurangnya kemampuan lemabag untuk memenuhi kesejahteraan yang layak bagi guru yang berdampak kepada kurang maksimalnya pelayanan pendidikan yang diberikan. Adapun kendala secara fisik adalah bangunan pondok pesantren, dan sarana ibadah seperti masjid. Kurangnya sarana ini menyebabkan pihak pesantren harus membatasi penerimaan santri karena tidak mencukupi lagi pondok untuk pemondokan.

Hal di atas juga sebagaimana yang terjadi di Dayah Darul Aitami Simeulue bahwa yang menjadi problematika pembentukan karakter di dayah Darul Aitami kabupaten Simeulue ialah kurangnya dana operasional yang diberikan, masalah honor tenaga pengajar, masalah kebutuhan asrama, masalah kebutuhan ATK, masalah kekurangan guru, dan malah sumber air bersih, itu semua menjadi problem bagi dayah Darul Aitami untuk membentuk karakter santri. Sebagaimana yang diungkapkan pihak dayah bahwa "masalah yang dihadapi dalam pembentukan karakter adalah masalah dana operasional, honorer guru, kebutuhan asrama, masalah ATK, masalah kekurangan guru dan masalah sumber air bersih".

Biasanya dayah/pesantren yang ada di Aceh dikelola secara perseorangan. Dalam hal ini, keuangan lembaga sangat tergantung pada kemampuan pimpinan dan sumbangan yang diberikan oleh masyarakat. Maka tidak mengherankan jika banyak dayah yang tidak siap secara finansial 
dalam mengelola keberlangsungan pendidikan. Hal ini merupakan permasalahan yang hampir dialami oleh semua dayah yang ada di Aceh. Baru kemudian setelah adanya Badan Dayah Aceh, dayah-dayah sudah terbantu anggarannya dan dapat membayar gaji teungku secara lebih layak.

Berdasarkan hasil penelitian di atas, dapat di pahami bahwa problematika yang dihadapi oleh dayah-dayah di Aceh sangat beragam tergantung geografis dan demografis masing-masing wilayah. Namun demikian, dapat ditarik "benang merah" bahwa problematika tersebut merupakan pekerjaan rumah bagi badan Dayah Aceh dan setiap dayah yang ada di Aceh untuk terus berbenah dan melakukan inovasi-inovasi sehingga pembentukan karakter remaja dan santri yang ada di Aceh dapat tercapai dengan baik.

Sebagai bahan kajian, penulis juga menawarkan suatu konsep sebagaimana di kutip dalam fauzan (2015) bahwa agar konsep pendidikan karakter di pesantren dapat berlangsung dengan maksimal, tentunya diperlukan formula dalam prakteknya. Doni Koesoema dalam fauzan (2015)memberikan formula bahwa penddikan karakter jika ingin efektif dan utuh harus menyertakan tiga basis desain pemrogramannya yaitu; (1) desain pendidikan berbasis kelas, (2) desain pendidikan karakter berbasis kultur sekolah atau pesantren, dan (3) desain pendidikan karakter berbasis komunitas.

a. Desain pendidikan karakter berbasis kelas

Desain ini berbasis pada relasi para guru/ustad sebagai pendidik dan siswa/santri sebagai pelajar di dalam kelas. Konteks pendidikan karakter adalah proses relasional komunitas kelas dalam konteks pembelajaran. Relasi guru-pelajar bukan monolog, melainkan dialog dengan banyak arah sebab komunitas kelas terdiri atas guru dan siswa yang sama-sama berinteraksi dengan materi. Memberikan pemahaman dan pengertian akan keutamaan yang benar terjadi dalam konteks pengajaran ini, termasuk didalamnya pula adalah ranah noninstruksional, seperti manajemen kelas, dan lain-lain, yang membantu terciptanya suasana yang nyaman. Dalam konteks pendidikan karakter di pesantren, kegiatan pembelajarn harian dilaksanakan di lingkungan masjid atau musholla ataupun ruangan tertentu yang dijadikan tempat belajar dengan ustad yang bertindak sebagai fasilitator dan mediator pembelajaran

b. Desain pendidikan karakter berbasis sekolah/pesantren

Desain ini mencoba membangun kultur sekolah yang mampu membentuk karakter anak didik dengan bantuan pranata social sekolah/pesantren agar nilai terbentuk dan terbatinkan dalam diri siswa/santri.Untuk menanamkan kejujuran misalnya, tidak cukup hanya dengan memberikan pesan-pesan moral kepada anak didik. Pesan moral ini mesti diperkuat dengan penciptaan kultur kejujuran melalui pembuatan tata peraturan sekolah yang tegas dan konsisten terhadap setiap perilaku ketidakjujuran. Dalam konteks pendidikan karakter berbasis kultur pesantren dilaksanakan dengan menata lingkungan fisik pesantren dan pembuatan tata tertib pesantren yang bernuansa nilai-nilai Islam.

c. Desain pendidikan karakter berbasis komunitas.

Dalam mendidik, komunitas sekolah/pesantren tidak berjuang sendirian. Masyarakat di luar lembaga/pesantren memiliki tanggung jawab moral untuk mengintegrasikan pembentukan karakter dalam konteks kehidupan mereka. Ketika lembaga lemah dalam penegakan hukum, ketika mereka yang bersalah tidak mendapatkan sanksi yang 
setimpal, lembaga telah mendidik masyarakatnya untuk menjadi manusia yang tidak menghargai makna tatanan sosial bersama. Dalam konteks pendidikan karakter di pesantren, implementasi desain pendidikan karakter berbasis komunitas dikembangkan dengan membuat kelompok-kelompok belajar dan mengembangkan program pengembangan diri.

Penerapan penndidikan karakter di pesantren tentunya akan bisa efektif jika tiga desain pendidikan karakter ini dilaksakan secara simultan dan sinergis. Mengabaikan ketiga desain tersebut, pendidikan hanya akan bersifat parsial, inkonsisten, dan tidak etektif.

\section{KESIMPULAN}

Dayah merupakan salah satu lembaga pendidikan yang sudah sejak zaman kemerdekaan bahkan sebelumnya. Dayah salah satu tempat menuntut ilmu-ilmu agama. Di hati masyarakat Aceh Dayah salah satu lembaga pendidikan yang mengangkat marwah bangsa Aceh dan banyak mencetak-cetak ulama yang terkenal hingga ke manca-negara. Di dayah, pendidikan karakter bukanlah hal yang baru, sebab sejak dini meanstream (pengarusutamaan) karakter santri sudah dikedepankan melalui pendidikan akhlak. Di dayah persoalan akhlak menjadi persoalan yang sangat urgen, sebenarnya pesantren telah lama mendidik santrinya agar memiliki karakter yang dapat diandalkan, seperti karakter bidang keilmuan, karakter bidang akhlak dan karakter bidang sosial. Namun dalam prosesnya, tetap ada problematika yang harus dihadapi oleh dayah dalam usaha membentuk karakter santri di Aceh. Problematika yang dihadapi oleh masing-masing dayah ini berbeda-beda. Setidaknya ada tiga problematika yang dihadapi dayah dalam pembentukan karakter yaitu 1) Sains dan teknologi, 2) Dukungan orangtua, dan 3) Kesiapan lembaga Pendidikan dayah. 


\section{DAFTAR PUSTAKA}

Alwi, B. M. (2014). Pendidikan Karakter: Solusi Bijak Menyikapi Perilaku Menyimpang Anak. Alauddin University Press.

Arifin, H. M. (1996). Ilmu pendidikan Islam: suatu tinjauan teoritis dan praktis berdasarkan pendekatan interdisipliner. Bumi Aksara.

Arifin, Z. (2014). BUDAYA PESANTREN DALAM MEMBANGUN KARAKTER SANTRI. Paper Knowledge . Toward a Media History of Documents, 5(2), 40-51. http://ejournal.kopertais4.or.id/tapalkuda/index.php/qodiri/article/view/1158

Bahrudin, \& Rifa'i, M. (2021). Implementasi Pembelajaran Kitab Kuning Sebagai Upaya Pembentukan Karakter Religius Santri. TA'LIM : Jurnal Studi Pendidikan Islam, 4(1), 1 21. http://www.e-jurnal.unisda.ac.id/index.php/talim/article/view/2127/1426

Dhofier, Z. (1984). Tradisi Pesantren, Studi tentang Pandangan Hidup Kyai. In Archipel (Vol. 28, Issue 1).

Fauzan, F. (2015). PERAN PESANTREN DALAM MENGEMBANGKAN PENDIDIKAN KARAKTER. El-Furqania : Jurnal Ushuluddin Dan Ilmu-Ilmu Keislaman, 1(01). http://ejournal.kopertais4.or.id/madura/index.php/elfurqania/article/view/881

Fitri, A. (2018). Pendidikan Karakter Prespektif Al-Quran Hadits. TA'LIM : Jurnal Studi Pendidikan Islam, 1(2), 258-287. http://www.ejurnal.unisda.ac.id/index.php/talim/article/view/952

Fuad, A. J. (2012). PENDIDIKAN KARAKTER DALAM PESANTREN TASAWUF. Tribakti: Jurnal Pemikiran Keislaman, 23(1). https://doi.org/10.33367/TRIBAKTI.V23I1.13

Hendayani, M. (2019). Problematika Pengembangan Karakter Peserta Didik di Era 4.0. Jurnal Penelitian Pendidikan Islam, 7(2), 183. https://doi.org/10.36667/jppi.v7i2.368

Lickona, T. (2009). Educating for character: How our schools can teach respect and responsibility. Bantam Books.

Mahalli, A. M. E. S. (2018). KONTRIBUSI DAYAH DARUL AZHAR DALAM PENERAPAN SYARIAT ISLAM DI KABUPATEN ACEH TENGGARA. At-Tazakki: Jurnal Kajian Ilmu Pendidikan Islam Dan Humaniora, 2(1), 74-90. http://jurnal.uinsu.ac.id/index.php/attazakki/article/view/1447

Maruf, M. (2018). Nilai-Nilai Edukatif Dalam Tasawuf: Telaah Terhadap Tawajuhan Pada Thariqah Qodiriyyah Wa Naqsabandiyyah (Studi Kasus Di Pondok Pesantren Cabean .... In Jurnal Al-Makrifat. https://core.ac.uk/download/pdf/234800648.pdf

Mashuri, M. (2013). DINAMIKA SISTEM PENDIDIKAN ISLAM DI DAYAH. Jurnal Ilmiah Didaktika, 13(2). https://doi.org/10.22373/jid.v13i2.477

Masnur, M. (2011). Pendidikan Karakter Menjawab Tantangan Krisis Multidimensional. Bumi Aksara.

Megawangi, R. (2004). Pendidikan karakter solusi yang tepat untuk membangun bangsa.

Munawwaroh, A. (2019). Keteladanan Sebagai Metode Pendidikan Karakter. Jurnal Penelitian Pendidikan Islam, 7(2), 141. https://doi.org/10.36667/jppi.v7i2.363

Novita, L., Hastuti, D., Tin, D., Fakultas, H., Manusia, E., \& Pertanian Bogor, I. (2015). PENGARUH IKLIM KELUARGA DAN KETELADANAN ORANG TUA TERHADAP KARAKTER REMAJA PERDESAAN. Jurnal Pendidikan Karakter, 6(2). 
https://doi.org/10.21831/jpk.v0i2.8622

Park, N., \& Peterson, C. (2006). Moral competence and character strengths among adolescents: The development and validation of the Values in Action Inventory of Strengths for Youth. Journal of Adolescence, 29(6), 891-909. https://doi.org/10.1016/j.adolescence.2006.04.011

Ryan, K., \& Bohlin, K. E. (1999). Building character in schools: Practical ways to bring moral instruction to life. Jossey-Bass Inc., Publishers.

Sumardi, K. (2012). POTRET PENDIDIKAN KARAKTER DI PONDOK PESANTREN SALAFIAH. Jurnal Pendidikan Karakter, 3(3), 120364. https://doi.org/10.21831/jpk.v0i3.1246

Triyono, A. (2017). Peran Pesantren dalam Pembentukan Karakter Bangsa. As-Salam, 6(1), 91108. https://doi.org/10.53961/JURNALPARADIGMA.V1I1.12

Ubaidillah, A. F. (2016). Pembentukan Karakter Religius dan Mandiri Melalui Model Pendidikan ala Pondok Pesantren. Al-Wijdan: Journal of Islamic Education Studies, 1(1), $1-16$.

Zarkasyi, A. S. (2005). Gontor dan Pembaharuan pendidikan Pesantren. Raja Grapindo Persada. 